\title{
The impact of hepatitis B knowledge and stigma on screening in Canadian Chinese persons
}

\author{
Dorothy Li MD², Taryn Tang $\mathrm{PhD}^{2}$, Matt Patterson $\mathrm{PhD}(\mathrm{c})^{3}$, \\ Michael Ho MD CCFP ${ }^{4}$, Jenny Heathcote MBBS MD FRCP FRCPC ${ }^{1}$, Hemant Shah MD MScCH HPTE FRCPC ${ }^{1}$
}

D Li, T Tang, M Patterson, M Ho, J Heathcote, H Shah. The impact of hepatitis B knowledge and stigma on screening in Canadian Chinese persons. Can J Gastroenterol 2012;26(9): 597-602.

BACKGROUND: Chronic hepatitis B (CHB) infection is endemic in East Asia, and those who emigrate to North America have higher rates of $\mathrm{CHB}$ infection when compared with the general population. To date, Chinese persons residing in Canada have not been mandated to be screened for $\mathrm{CHB}$ infection.

OBJECTIVE: To understand factors that influence hepatitis B screening behaviour among the Chinese community in Toronto, Ontario, and to determine whether stigma acts as a barrier to screening.

METHODS: Self-identified Chinese individuals at a family physician's office and at English as a second language (ESL) classes in Toronto completed a questionnaire with demographic questions, a hepatitis $\mathrm{B}$ virus (HBV) stigma scale and an HBV knowledge scale. Pearson product moment correlation and multiple regression techniques were used to analyze the data.

RESULTS: The study group included 343 individuals. Their mean ( \pm SD) age was $48.76 \pm 17.49$ years and the majority were born in China $(n=229[68 \%])$. The mean score on the HBV knowledge scale was $10.13 \pm 1.76$ (range 0 to 15 ), with higher scores indicating greater HBV knowledge. The mean score on the stigma scale was $54.60 \pm 14.18$ (range 20 to 100), with higher scores indicating more stigma. Being an immigrant, having a family physician and having greater knowledge of HBV were associated with increased rates of screening for this infection. In contrast, greater levels of HBV stigma were associated with decreased likelihood of screening for HBV infection.

CONCLUSIONS: HBV stigma is associated with reduced rates of screening for this infection.

Key Words: Hepatitis B; Knowledge; Mass screening; Social stigma
Les conséquences des connaissances sur l'hépatite B et l'opprobre du dépistage chez des Canadiens d'origine chinoise

HISTORIQUE : L'infection par l'hépatite B chronique (HBC) est endémique en Extrême-Orient, et les personnes qui émigrent en Amérique du Nord présentent un taux plus élevé d'infection par l'HBC que l'ensemble de la population. Jusqu'à présent, les Chinois qui habitent au Canada ne sont pas soumis au dépistage de l'infection par l'HBC.

OBJECTIF : Comprendre les facteurs qui influent sur le comportement envers le dépistage de l'hépatite $\mathrm{B}$ au sein de la communauté chinoise de Toronto, en Ontario, et déterminer si l'opprobre constitue un obstacle au dépistage.

MÉTHODOLOGIE : Des personnes qui se disaient d'origine chinoise et qui fréquentaient le cabinet d'un médecin de famille ou des cours d'anglais langue seconde (ALS) à Toronto ont rempli un questionnaire comportant des questions d'ordre démographique, une échelle de l'opprobre lié au virus de l'hépatite B (VHB) et une échelle des connaissances sur le VHB. Les auteurs ont utilisé la corrélation produitmoment de Pearson et des techniques de régression multiple pour analyser les données.

RÉSULTATS : Le groupe d'étude se composait de 343 personnes, d'un âge moyen ( \pm ÉT) de 48,76 $\pm 17,49$ ans, dont la majorité était née en Chine ( $\mathrm{n}=229$ [68\%]). L'indice moyen de l'échelle des connaissances sur le VHB s'élevait à $10,13 \pm 1,76$ (plage de 0 à 15 ), des indices plus élevés indiquant de meilleures connaissances sur le VHB. L'indice moyen de l'échelle d'opprobre correspondait à 54,60 14,18 (plage de 20 à 100), les indices plus élevés étant indicateurs d'un plus grand opprobre. Le fait d'être immigrant, d'avoir un médecin de famille et de mieux connaître le VHB était inversement proportionnel au dépistage de l'infection par le VHB.

CONCLUSIONS : L'opprobre lié au VHB s'associe à une diminution du taux de dépistage de cette infection.

range as low as $37 \%$ to $65 \%(8,20)$. Infected individuals who fail to get screened and diagnosed may not be considered for interventions that could reduce morbidity and mortality (22).

Previous frameworks have been created to describe and understand the factors determining patient use of health care. According to Andersen's 'Behavioural Model of Health Services Use' (23), predisposing characteristics, enabling factors and need for care all influence the use of health services. Previous studies have provided insight into some of these influences on health behaviour in the context of HBV infection in North American Chinese individuals. Factors previously shown to be associated with screening for HBV infection include HBV knowledge and recommendation for screening by physicians, family and friends $(8,20,21,24-29)$. Surprisingly, few studies have examined barriers to HBV screening $(7,30)$. A previous study conducted among Toronto Chinese individuals examined sociocultural factors influencing HBV prevention and treatment. In that study, participants with $\mathrm{CHB}$ felt stigmatized because of their infection. Only $47 \%$ were willing to discuss their illness with their friends or family (30). rates of screening for HBV infection among North American Chinese

${ }^{1}$ Department of Medicine; ${ }^{2}$ Department of Psychiatry; ${ }^{3}$ Department of Sociology, University of Toronto; ${ }^{4}$ Family Physician, Toronto, Ontario

Correspondence: Dr Hemant Shah, Toronto Western Hospital, 6B FP-176, 399 Bathurst Street, Toronto, Ontario M5T 2 S8.

Telephone 416-603-5695, fax 416-603-6281, e-mail hemant.shah@uhn.ca

Received for publication September 11, 2011. Accepted December 27, 2011 


1. People with Hepatitis B should be isolated from others to protect the
public.
2. It is not safe for people with Hepatitis B to work with children.
3. People with Hepatitis B should not be allowed to work in certain
areas such as restaurants.
4. I would feel pity for someone with Hepatitis B.
5. A person with Hepatitis B must have done something wrong and
deserves to be sick.
6. Parents are at fault for their children getting Hepatitis B.
7. People with Hepatitis B should be ashamed of their illness.
8. People with Hepatitis B are unclean.
9. I would not want my child to attend school where one of the students
had Hepatitis B.
10. I would not want to work in an office where one of people had
Hepatitis B.
11. I would not want to go to a small neighbourhood grocery store where
the owner had Hepatitis B.
12. I would feel uncomfortable wearing a sweater once worn by a person
with Hepatitis B.
13. I would feel uncomfortable sharing a meal with someone who has
Hepatitis B.
14. I would not want to be friends with someone with Hepatitis B.
15. I would not employ someone with Hepatitis B to work for me.
16. I would feel uncomfortable having a conversation with someone who
has Hepatitis B.
17. I would not kiss someone with Hepatitis B.
18. I would not date someone with Hepatitis B.
19. I would not marry someone with Hepatitis B.
20. I would avoid rooming with someone with Hepatitis B.
(a)

Figure 1) Hepatitis B stigma questionnaire. Study participants were asked to indicate with an ' $X$ ' on a Likert scale of 1 (strongly disagree) to 5 (strongly agree) with each of the statements listed

According to Goffman (31), stigma is "an attribute that links a person to an undesirable stereotype, leading other people to reduce the bearer from a whole and usual person to a tainted, discounted one". It exerts its effects by threatening or causing the loss of what is most at stake for an individual (32). In Chinese societies, which are collectivist in nature and place emphasis on interdependence, stigma threatens an individual's social connections, status and resources (33). Stigmatization, and its associated fears, creates an environment of secrecy and denial, thereby preventing individuals at risk of a stigmatized disease from seeking screening, prevention and treatment (34). Stigma has been shown to exert substantial influence on health behaviour in Chinese society in the context of other infectious diseases such as HIV/AIDS (34). However, the influence of stigma on the health behaviour of Chinese individuals in the context of HBV infection has not been thoroughly examined.

The current study aimed to understand the factors influencing HBV screening behaviour among Chinese individuals residing in Toronto and to determine whether stigma acts as a barrier to screening for this infection.

\section{METHODS}

Participant selection and recruitment

The present study was conducted using a convenience sample recruited from two sites in downtown Toronto. One group was recruited from the office of a general physician that serves a mainly Chinese population, and the other was recruited from English as a Second Language (ESL) classes at a Chinese community centre. Inclusion criteria were self-identified Chinese ethnicity, ability to read and write Cantonese, Mandarin or English, and ability to provide informed consent. Individuals who did not meet all of the above criteria were excluded from the study.
Consecutive individuals were approached and informed about the study at the family physician's office by the first author in the language of choice for each participant: either English, Cantonese or Mandarin. At the community centre, a general announcement delivered in person by the first author was made to each ESL class regarding the study in Cantonese or Mandarin. At both sites, those who were interested were given more detailed information about the study and had the opportunity to ask questions. Once informed written consent was obtained, participants were asked to complete the written questionnaire on site. Questionnaires were available in English, and in traditional and simplified Chinese. The first author was available to answer any questions that arose during the process. On completion of the questionnaire, participants were offered financial compensation of $\$ 10$. This protocol was approved by the University Health Network Research Ethics Board (Toronto, Ontario).

\section{Survey instrument}

A written questionnaire was used to assess participant demographics, health care utilization, HBV stigma and HBV knowledge. Demographic questions included sex, age, birthplace and duration of residency in Canada. Questions pertaining to health care included whether they had a family doctor and if they had undergone previous screening for, vaccination against, or treatment for HBV infection. The questionnaire was developed in English, translated into traditional and simplified Chinese, and back-translated to English to ensure accuracy.

\section{Toronto Chinese HBV Stigma Scale}

The Toronto Chinese HBV Stigma Scale was included in the questionnaire to measure stigmatizing attitudes toward HBV infection (Figure 1). This scale was developed by a team of experts in Social and Cultural Epidemiology and Hepatology at the University of Toronto (Toronto, Ontario) to serve as a reliable and comprehensive clinical and research tool for measuring one's level of stigma and was previously tested in a small sample of 28 individuals. The scale consists of 20 items derived and modified from stigma scales in the literature for HIV/AIDS. The items were selected using factor analysis to ensure internal consistency of the scale. Each item consisted of a statement pertaining to HBV stigma, such as, "People with hepatitis B should be isolated from others to protect the public" or "People with hepatitis B are unclean". Participants were asked to indicate their opinion on a five-point Likert scale ( 1 = strongly disagree, 5 = strongly agree). Higher scores indicate greater levels of HBV stigma. There is no absolute cut-off value demarcating the presence or absence of HBV stigma. Cronbach's alpha for the 20 -item scale was 0.90 , indicating excellent reliability of the scale. Details regarding the development and validation of The Toronto Chinese HBV Stigma Scale will be available in a future publication.

\section{HBV knowledge scale}

To assess HBV knowledge among study participants, a published scale was used (30). This 14-item scale evaluated participant knowledge of HBV infection. Most questions were of 'True or False' format and were derived from published surveys assessing HBV knowledge in the literature. This scale was previously used in a sample of Chinese individuals recruited from a family physician's office in Toronto (30).

\section{Statistical analysis}

Statistical analyses were directed by a conceptual framework based on the Behavioural Model of Health Service Use (23). According to this model, predisposing, enabling, impeding and needs factors all interact to influence an individual's health behaviour, such as the decision to seek screening for HBV infection. Using this model, variables were selected for completing the logistic regression to determine factors influencing HBV screening. Predisposing factors included were age, sex, education level, marital and parental status. Enabling and impeding factors included birthplace, years lived in Canada and English ability, which reflect one's acculturation status. Residency and citizenship status were also included, and individuals identified as an 
TABLE 1

\section{Results}

\begin{tabular}{|c|c|}
\hline Predisposing factors & \\
\hline Age, years, mean \pm SD & $48.76 \pm 17.489$ \\
\hline \multicolumn{2}{|l|}{ Sex } \\
\hline Female & $238(69.8)$ \\
\hline Male & $103(30.2)$ \\
\hline \multicolumn{2}{|l|}{ Married } \\
\hline Yes & $239(70.7)$ \\
\hline Other & $99(29.3)$ \\
\hline Has at least 1 child & $243(71.1)$ \\
\hline \multicolumn{2}{|l|}{ Education level } \\
\hline No formal education & $6(1.9)$ \\
\hline Home/primary school & $79(24.8)$ \\
\hline High school & $145(45.5)$ \\
\hline College/university & $82(25.7)$ \\
\hline Graduate/professional & $7(2.2)$ \\
\hline \multicolumn{2}{|l|}{ Enabling and impeding factors } \\
\hline \multicolumn{2}{|l|}{ Birthplace } \\
\hline Canada & $18(5.4)$ \\
\hline Immigrants (first generation): & $317(94.6)$ \\
\hline China & $229(68.4)$ \\
\hline Vietnam & $48(14.3)$ \\
\hline Hong Kong & $22(6.6)$ \\
\hline Taiwan & $4(1.2)$ \\
\hline Other & $14(4.2)$ \\
\hline \multicolumn{2}{|l|}{ Citizenship/residency status } \\
\hline Canadian-born & $18(5.5)$ \\
\hline Immigrant: Citizen & $181(55.2)$ \\
\hline Immigrant: Permanent resident & $120(36.6)$ \\
\hline Immigrant: Nonpermanent resident/other & $9(2.7)$ \\
\hline Years in Canada, mean $\pm S D$ & $14.66 \pm 12.044$ \\
\hline English ability (range 1-5), mean \pm SD & $2.408 \pm 1.259$ \\
\hline Has a family doctor & $323(95.8)$ \\
\hline HBV knowledge score (range 0-15), mean \pm SD & $10.13 \pm 1.764$ \\
\hline HBV Stigma score (range 20-100), mean \pm SD & $54.598 \pm 14.176$ \\
\hline \multicolumn{2}{|l|}{ Need factors } \\
\hline Knows someone with HBV infection & $105(31.8)$ \\
\hline \multicolumn{2}{|l|}{ Health behaviour } \\
\hline Known previous screening for HBV infection & $186(54.9)$ \\
\hline
\end{tabular}

Data presented as $n$ (\%) unless otherwise indicated. HBV Hepatitis $B$ virus

immigrant in the present study were first-generation immigrants who were born outside of Canada. Each individual was identified as a noncitizen immigrant (permanent resident), immigrant citizen or Canadian-born citizen. Other enabling and impeding factors included in the analysis were whether the individual had a family physician, level of HBV knowledge and HBV stigma. Knowing an individual infected with HBV was included in the data analysis as a need factor because this may influence ability to gain insight about the symptoms and general health status of infected individuals and influence recognition of the need for health services in relation to HBV infection (23). The recruitment site of each participant was also included as a control variable. Hierarchical logistic regression analysis was completed using variables based on the above-described model to determine factors influencing HBV infection screening. All associations with $\mathrm{P}<0.05$ were considered to be statistically significant. All analyses were performed using SPSS version 15.0 (IBM Coporation, USA) for Windows 2000 (Microsoft Corporation, USA).

\section{RESULTS}

Of the 434 individuals approached, 91 refused participation and 343 agreed to participate, resulting in a $79 \%$ participation rate. Two
TABLE 2

Hepatitis B Virus Knowledge Scale results

\begin{tabular}{|c|c|}
\hline Question & $\begin{array}{c}\text { Correct response } \\
\mathrm{n}(\%)\end{array}$ \\
\hline $\begin{array}{l}\text { In my opinion, hepatitis B can be transmitted via sexual } \\
\text { contact }\end{array}$ & $221(66)$ \\
\hline $\begin{array}{l}\text { In my opinion, hepatitis B can be transmitted from mother } \\
\text { to child at birth }\end{array}$ & $253(76.2)$ \\
\hline $\begin{array}{l}\text { In my opinion, hepatitis B can be transmitted by sharing } \\
\text { food }\end{array}$ & $96(28.5)$ \\
\hline In my opinion, hepatitis B can affect adults & $251(73.4)$ \\
\hline In my opinion, hepatitis B can affect children & $279(81.6)$ \\
\hline Do you know what cirrhosis is? (yes) & $177(54)$ \\
\hline In my opinion, hepatitis B can cause cirrhosis & $284(85)$ \\
\hline In my opinion, hepatitis B can cause liver cancer & $286(85.4)$ \\
\hline In my opinion, hepatitis B can be cured & $50(14.7)$ \\
\hline $\begin{array}{l}\text { In my opinion, hepatitis B is a transient infection - like the } \\
\text { flu }\end{array}$ & $249(73.9)$ \\
\hline In my opinion, there are effective treatments for hepatitis B & $313(92.6)$ \\
\hline In my opinion, there is a vaccination to prevent hepatitis B & $325(95.9)$ \\
\hline $\begin{array}{l}\text { In my opinion, people infected with hepatitis B often have } \\
\text { no symptoms }\end{array}$ & $272(81)$ \\
\hline $\begin{array}{l}\text { In my opinion, people with severe hepatitis B can have no } \\
\text { symptoms }\end{array}$ & $121(36.1)$ \\
\hline $\begin{array}{l}\text { In my opinion, healthy people with hepatitis B do not need } \\
\text { to be followed by a doctor }\end{array}$ & $288(85)$ \\
\hline
\end{tabular}

hundred twenty-three $(65 \%)$ were recruited at a family physician's office, and 120 (35\%) from ESL classes. Not every item on the questionnaire was answered by every participant. The results are summarized in Table 1.

The majority $(\mathrm{n}=238[69.8 \%])$ were women. The mean $( \pm \mathrm{SD})$ age was $48.76 \pm 17.49$ years, with a range of 19 to 92 years. Only $18(5.4 \%)$ participants were born in Canada; the majority were born in China $(n=229[68.4 \%])$. More than one-half of the participants were Canadian citizens $(n=199$ [60.7\%]). The mean number of years lived in Canada was $14.66 \pm 12.04$ years. The mean self-rated English ability was $2.41 \pm 1.26$, on a Likert scale of 1 to 5 , with higher scores indicating greater English proficiency. Most participants had a family doctor $(n=323[95.8 \%])$, with no significant difference between the group recruited from the family physician's office and the ESL class. Onethird of study participants $(n=105[31.8 \%])$ knew someone with an HBV infection.

The mean score on the HBV knowledge scale was $10.13 \pm 1.76$ of a maximum of 15 , with higher scores indicating greater HBV knowledge. The number and percentage of correct participant responses on each item of the questionnaire are shown in Table 2. The mean score on the stigma scale was $54.60 \pm 14.18$, with a possible range of 20 to 100 , with higher scores indicating greater HBV stigma.

More than one-half of the study group reported previous screening for HBV infection ( $\mathrm{n}=186$ [54.9\%]). Logistic regression analysis controlling for predisposing factors and enabling factors demonstrated that being an immigrant, having a family physician and having greater HBV knowledge were significantly associated with previous screening for HBV infection. Conversely, the only factor that significantly decreased the likelihood of previous screening for HBV infection was greater HBV stigma (Model 3 in Table 3).

\section{DISCUSSION}

There are various factors that exert positive and negative influences on HBV infection screening among Chinese individuals in Toronto. The present study was the first to report that HBV stigma significantly decreases the likelihood of getting screened for this infection.

Due to the risk of disease transmission, and subsequent physical and psychological morbidity and mortality, individuals with various 
TABLE 3

Multiple logistic regression for predicting hepatitis B virus (HBV) screening

\begin{tabular}{|c|c|c|c|c|c|c|c|}
\hline \multirow[b]{2}{*}{ Factor } & \multirow{2}{*}{$\begin{array}{c}\text { Zero order } \\
\text { corr }\end{array}$} & \multicolumn{2}{|c|}{ Model 1} & \multicolumn{2}{|c|}{ Model 2} & \multicolumn{2}{|c|}{ Model 3} \\
\hline & & $\mathrm{b}$ & SE & $\mathrm{b}$ & SE & $\mathrm{b}$ & SE \\
\hline Recruitment site & 0.096 & 0.158 & 0.271 & 0.136 & 0.365 & 0.186 & 0.370 \\
\hline \multicolumn{8}{|l|}{ Predisposing factors } \\
\hline Female sex & 0.015 & -0.223 & 0.278 & -0.237 & 0.300 & -0.239 & 0.301 \\
\hline Married & 0.062 & 0.424 & 0.327 & 0.190 & 0.361 & 0.190 & 0.363 \\
\hline Education level & 0.052 & 0.034 & 0.162 & 0.043 & 0.187 & 0.012 & 0.189 \\
\hline \multicolumn{8}{|l|}{ Enabling and impeding factors } \\
\hline Immigrant: Citizen & -0.067 & & & $1.618^{\star *}$ & 0.624 & $1.536^{\star}$ & 0.628 \\
\hline Immigrant: Permanent resident & $0.132^{*}$ & & & $1.721^{\star}$ & 0.709 & $1.593^{\star}$ & 0.716 \\
\hline Years in Canada & $-0.171^{\star *}$ & & & -0.012 & 0.016 & -0.009 & 0.016 \\
\hline English ability & -0.009 & & & -0.022 & 0.144 & -0.024 & 0.145 \\
\hline Has family doctor & $0.172^{\star \star}$ & & & $1.804^{*}$ & 0.846 & $1.667^{\star}$ & 0.850 \\
\hline Knows someone with HBV infection & $0.232^{\star *}$ & & & & & 0.419 & 0.314 \\
\hline CONSTANT & & 0.568 & 0.722 & -2.715 & 1.582 & -2.601 & 1.584 \\
\hline
\end{tabular}

${ }^{*} P<0.05 ;{ }^{*} P<0.01$. The table contains the results for each step of the hierarchical regression analysis. Each successive model adds an additional set of factors derived from the 'Behavioural Model of Health Services Use'. Model 3 contains all of the factors and is the primary model referenced in the results and discussion sections of the present article The zero-order column includes independent measures of correlation for each individual variable. As indicated by * or ** in the table, the factors significantly associated with previous screening for HBV infection include being an immigrant, having a family doctor and having greater HBV knowledge. HBV stigma had a significant and negative association with HBV infection screening

infectious diseases have been stigmatized throughout history $(34,35)$. In the case of HIV/AIDS, found in previous studies to be perceived as a dangerous illness with an overestimated risk of transmission through casual contact (35), individuals suspected of or living with this infection have been denied employment, refused entry to foreign countries, and excluded from their communities and workplaces (35). Findings from the present study indicate that similar fears of the consequences and contagiousness of disease play a role in the development and perpetuation of HBV stigma. Most participants (85\%) were aware that $\mathrm{CHB}$ infection is associated with serious health consequences such as cirrhosis and liver cancer. With regard to the contagiousness of disease, there was a common misconception among participants that HBV infection is transmissible by sharing food or eating utensils with infected individuals. This has been described in previous studies involving North American Chinese individuals $(21,25,30,36,37)$ and likely results from confusion about the routes of transmission of the many different hepatitis viruses. This misconception may contribute to HBV stigma through fear of biological contagiousness, manifest as discomfort among participants regarding sharing a meal with an infected individual (Stigma scale score $3.13 \pm 1.196$ ) and allowing infected individuals to work in restaurants (Stigma scale score $3.50 \pm 1.203)$. This perceived association between disease transmission and meal sharing may render the stigma of HBV particularly threatening in a collectivist culture such as that of the Chinese. Chinese societal organization consists of an intricate web of personal relationships formed among its members. 'Guanxi' are strategies used by members of a community to establish and strengthen bonds with one another, and sharing food with another person is a way of publicly acknowledging having 'guanxi.' (38). If HBV infection is believed to be transmissible by sharing food, fear of acquiring the infection may then deter others from engaging in these important bond-strengthening social interactions with individuals known to be infected with HBV. To avoid such consequences, infected individuals may refrain from disclosing their infection to others, and those who are at risk of infection may avoid screening for fear of diagnosis of disease and subsequent social isolation.
The present study also established factors positively associated with HBV screening. One such factor was being a first-generation immigrant. Prospective immigrants are required to undergo health screening in the application process to emigrate to Canada (39). While they are advised to see a family physician after their arrival in this country, new immigrants are not required to undergo screening for HBV infection $(39,40)$. Even so, family physicians who are aware of the increased risk of HBV infection among these individuals may proceed with appropriate screening and, thereby, account for the increased likelihood of screening among immigrants in the present study.

Consistent with the literature, the current study found that greater knowledge about HBV infection is associated with screening for this infection $(8,20,21,24-29)$. The present study also confirmed previous reports of a positive association between having a family physician and HBV screening (9). This is not surprising, given that family physicians are the gateway to health care services and serve as a resource of health knowledge and disease awareness. However, there is still room for further improvement. Although the large majority of individuals in the present study had a family physician, almost one-half did not report previous screening for HBV infection. Granted, screening may have been under-reported by participants due to erroneous recall. However, low screening rates may be the result of limited knowledge among family physicians regarding indications for and appropriate tests for screening for HBV infection (41). This association between health care provider HBV knowledge and patient screening has been demonstrated previously in a study conducted in San Francisco, USA (8). In that study, one-third of family physicians did not know the appropriate test to order to screen for HBV infection. Additionally, a recent survey of family medicine residents across Canada indicates that only $42 \%$ routinely ask about HBV risk factors, and $49 \%$ knew the appropriate screening tests for HBV (41). Overall, rates of screening for HBV infection among Chinese individuals remain far from optimal, and family physicians may help bridge this gap by gaining awareness of and implementing guidelines to screen populations at risk for $\mathrm{CHB}$, such as individuals from HBV-endemic areas. 
There are several limitations to the present study. First, it was conducted among Chinese residents of downtown Toronto. The demographics of this population may differ from residents of suburban areas or other North American cities; therefore, findings may not be generalized to these other groups. Second, individuals who consented to participate in the study may have inherent differences in demographics, resources, or health behaviours than those (albeit few) who refused participation or those who attended neither the family physician's office or ESL classes. Third, it would have been ideal to recruit more participants without a family physician to compare HBV screening, knowledge and stigma in those with and without regular access to health care. Furthermore, information regarding HBV infection status was not collected, but may have been known by the individual. As a result, comparison of HBV stigma levels between individuals with and without known HBV infection could not be conducted. Fourth, study data regarding health care exposures such as having a family physician and previous HBV infection screening were self-reported by participants, which may be inaccurate due to erroneous recall. Finally, the limitations of the statistical method should be noted. While regression analysis was based on a theoretical model of causation, it does not in itself prove causality. Based on existing literature and theory, stigma has been conceptualized in the present study as an independent variable and tested as a possible determinant of screening behaviour. The correlation that was discovered provides evidence for this relationship and suggests the value of further longitudinal research that would provide more definitive proof of causal direction.

\section{SUMMARY}

The present study demonstrated that there are multiple factors influencing who among Chinese individuals gets screened for HBV infection. Because stigma was shown to have a significant negative association with screening behaviour, reducing or eliminating HBV stigma may have a positive impact on screening behaviour. In addition to attempts to reduce stigma, it appears that enhancing awareness and knowledge about HBV infection and its consequences may help improve rates of screening for HBV infection.

AUTHOR CONTRIBUTIONS: Dorothy Li, the first author, designed the study, acquired and analyzed the data, and drafted, revised and approved the final version of the manuscript submitted for publication. Taryn Tang contributed to study design and data analysis, participated in draft review and revision, and approved the final version of the manuscript for submission. Matt Patterson contributed to data analysis, participated in draft review and revision, and approved the final version of the manuscript for submission. Michael Ho contributed to study design, participated in draft review and revision, and approved the final version of the manuscript for submission. Jenny Heathcote contributed to study design and data analysis, draft review and revision, and approved the final version of the manuscript for submission. Hemant Shah contributed to study design and data analysis, draft review and revision, and approved the final version of the manuscript for submission.

DISCLOSURES: The authors have no financial disclosures or conflicts of interest to declare.

SOURCES OF SUPPORT: Internal grant from Toronto Western Hospital Liver Clinic.

\section{REFERENCES}

1. World Health Organization. Fact sheet no. 204; Hepatitis B; 2008 <www.who.int/mediacentre/factsheets/fs204/en/index.html> (Accessed September 8, 2010).

2. Custer B, Sullivan SD, Hazlet TK, Iloeje U, Veenstra DL, Kowdley KV. Global epidemiology of hepatitis B virus. J Clin Gastroenterol 2004;38(10 Suppl 3):S158-68.

3. Sun Z, Ming L, Zhu X, Lu J. Prevention and control of hepatitis B in China. J Med Virol 2002;67:447-50.
4. Merican I, Guan R, Amarapuka D, et al. Chronic hepatitis B virus infection in Asian countries. J Gastroenterol Hepatol 2000;15:1356-1361

5. Lu J, Zhou Y, Lin X, et al. General epidemiological parameters of viral hepatitis $\mathrm{A}, \mathrm{B}, \mathrm{C}$, and $\mathrm{E}$ in six regions of china: $\mathrm{A}$ crosssectional study in 2007. PloS One 2009;4:e8467.

6. Wu PC, Comfort MB, Lin HJ. Epidemiological study of hepatitis B virus infection in a dental outpatient population. J Hong Kong Med Assoc 1989;41:351-4.

7. Hsu CE, Liu LC, Juon HS, et al. Reducing liver cancer disparities: A community-based hepatitis-B prevention program for AsianAmerican communities. J Natl Med Assoc 2007;99:900-7.

8. Lai CJ, Nguyen TT, Hwang J, Stewart SL, Kwan A, McPhee SJ. Provider knowledge and practice regarding hepatitis B screening in Chinese-speaking patients. J Cancer Educ 2007;22:37-41.

9. Guane R, Siu P, Lam K, et al. Prevalence of HBV and risk of HBV acquisition in hepatitis B screening programs in large metropolitan cities in the United States. Hepatology 2004;40(4 Suppl 1):716A (Abst).

10. Chao S, Le VP, Prapong W, Su J, So S. High prevalence of chronic hepatitis $\mathrm{B}(\mathrm{HBV})$ infection in adult Chinese Americans living in California. Hepatology 2004;40(4 Suppl 1):717A (Abst).

11. Centers for Disease Control and Prevention (CDC). Screening for chronic hepatitis B among Asian/Pacific Islander populations. New York City, 2005. MMWR. Morbidity and Mortality Weekly Report. 2006;55:505-509. <www.cdc.gov/mmwr/pdf/wk/mm5518.pdf> (Accessed April 22, 2009).

12. Lin SY, Chang ET, So SK. Why we should routinely screen Asian American adults for hepatitis B: A cross-sectional study of Asians in California. Hepatology 2007;46:1034-40.

13. Ugwu C, Varkey P, Bagniewski S, Lesnick T. Sero-epidemiology of hepatitis $\mathrm{B}$ among new refugees to Minnesota. J Immigr Minor Health 2008;10:469-74.

14. Beasley RP. Hepatitis B virus: The major etiology of hepatocellular carcinoma. Cancer 1988;61:1942-56.

15. Ganem D, Prince AM. Hepatitis B virus infection - natural history and clinical consequences. N Engl J Med 2004;350:1118-29.

16. Canadian Cancer Society's Steering Committee on Cancer Statistics. Canadian Cancer Statistics 2011. Toronto, ON: Canadian Cancer Society; 2011. <www.cancer.ca/Canada-wide/ About\%20cancer/ /media/CCS/Canada\%20wide/Files\%20List/ English\%20files\%20heading/PDF\%20-\%20Policy\%20-\%20 Canadian\%20Cancer\%20Statistics\%20-\%20English/Canadian\%20 Cancer\%20Statistics\%202011\%20-\%20English.ashx> (Accessed July 7, 2011).

17. Statistics Canada. Ethnic origins, 2006 counts, for Canada, provinces and territories $-20 \%$ sample data. 2006. <www 12 . statcan.ca.myaccess.library.utoronto.ca/census-recensement/2006/ $\mathrm{dp}-\mathrm{pd} / \mathrm{hlt} / 97-562 /$ pages $/$ page.cfm? $\mathrm{Lang}=\mathrm{E} \& \mathrm{Geo}=\mathrm{PR} \&$ Code $=01 \& \mathrm{Da}$ ta $=$ Count $\&$ Table $=2 \&$ StartRec $=1 \&$ Sort $=3 \&$ Display $=$ All $\&$ CSDFilte $\mathrm{r}=5000>$ (Accessed February 20, 2010).

18. Statistics Canada. Ethnic origins, 2006 counts, for census metropolitan areas and census agglomerations $-20 \%$ sample data: Toronto, CMA (Ont.) 2006. <www12.statcan.ca.myaccess.library. utoronto.ca/census-recensement/2006/dp-pd/hlt/97-562/pages/page.c $\mathrm{fm} ?$ Lang $=\mathrm{E} \& \mathrm{Geo}=\mathrm{CMA} \&$ Code $=535 \&$ Data $=$ Count $\&$ Table $=2 \&$ Sta $\mathrm{rtRec}=1 \&$ Sort $=3 \&$ Display $=$ All\&CSDFilter $=5000>($ Accessed February 20, 2010).

19. Lok AS, McMahon BJ. Chronic hepatitis B: Update 2009. Hepatology 2009;50:661-2.

20. Ma GX, Shive SE, Toubbeh JI, Tan Y, Wu D. Knowledge, attitudes, and behaviors of Chinese hepatitis B screening and vaccination. Am J Health Behav 2008;32:178-87.

21. Wu CA, Lin SY, So SK, Chang ET. Hepatitis B and liver cancer knowledge and preventive practices among Asian Americans in the San Francisco Bay Area, California. Asian Pac J Cancer Prev 2007;8:127-34.

22. Weinbaum CM, Williams I, Mast EE, et al. Centers for Disease Control and Prevention. Recommendations for identification and public health management of persons with chronic hepatitis $B$ virus infection. MMWR Recomm Rep. 2008 Sep;57(RR-8):1-20.

23. Andersen RM. Revisiting the behavioral model and access to medical care: Does it matter? J Health Soc Behav 1995;36:1-10.

24. Hislop TG, The C, Low A, et al. Hepatitis B knowledge, testing and vaccination levels in Chinese immigrants to British Columbia, Canada. Can J Public Health 2007;98:125-9. 
25. Hislop TG, The C, Low A, et al. Predisposing, reinforcing and enabling factors associated with hepatitis B testing in Chinese Canadians in British Columbia. Asian Pac J Cancer Prev 2007;8:39-44.

26. Thompson MJ, Taylor VM, Yasui Y, et al. Hepatitis B knowledge and practices among Chinese Canadian women in Vancouver, British Columbia. Can J Public Health 2003;94:281-6.

27. Coronado GD, Taylor VM, Tu SP, et al. Correlates of hepatitis B testing among Chinese Americans. J Community Health 2007;32:379-90.

28. Tu RSP, Li L, Tsai JH, et al. A cross-border comparison of hepatitis B testing among Chinese residing in Canada and the United States. Asian Pac J Cancer Prev 2009;10:483-90.

29. Nguyen TT, Taylor V, Chen MS Jr, Bastani R, Maxwell AE, McPhee SJ. Hepatitis B awareness, knowledge, and screening among Asian Americans. J Cancer Educ 2007;22:266-72.

30. Wu H, Yim C, Chan A, Ho M, Heathcote J. Sociocultural factors that potentially affect the institution of prevention and treatment strategies for prevention of hepatitis B in Chinese Canadians. Can J Gastroenterol 2009;23:31-6.

31. Goffman E. Stigma: Notes on the management of spoiled identity. Englewood Cliffs: Prentice Hall, 1963.

32. Yang LH, Kleinman A, Link BG, Phelan JC, Lee S, Good B. Culture and stigma: Adding moral experience to stigma theory. Soc Sci Med 2007;64:1524-35.

33. Rao D, Angell B, Lam C, Corrigan P. Stigma in the workplace: Employer attitudes about people with HIV in Beijing, Hong Kong, and Chicago. Soc Sci Med 2008;67:1541-9.
34. Lieber E, Li L, Wu Z, Rotheram-Borus MJ, Guan J; National Institute of Mental Health (NIMH) Collaborative HIV Prevention Trial Group. HIV/STD stigmatization fears as health-seeking barriers in China. AIDS Behav 2006;10:463-71.

35. Mak WW, Mo PK, Cheung RY, Woo J, Cheung FM, Lee D. Comparative stigma of HIV/AIDS, SARS, and tuberculosis in Hong Kong. Soc Sci Med 2006;63:1912-22.

36. Taylor VM, Tu SP, Woodall E, et al. Hepatitis B knowledge and practices among Chinese immigrants to the United States. Asian Pac J Cancer Prev. 2006;7:313-7.

37. Taylor VM, Coronado G, Acorda E, et al. Development of an ESL curriculum to educate Chinese immigrants about hepatitis B. J Community Health 2008;33:217-24.

38. Yang LH, Kleinman A. 'Face' and the embodiment of stigma in China: the cases of schizophrenia and AIDS. Soc Sci Med 2008;67:398-408.

39. Citizenship and Immigration Canada. Medical exam requirements for permanent residents. <www.cic.gc.ca/english/information/medical/medexams-perm.asp > (Accessed September 8, 2010).

40. Citizenship and Immigration Canada: Health Management Branch. Chapter 11: Canadian Immigration Medical Examinations. In: Designated Medical Practitioner Handbook. $<$ www.cic.gc.ca/english/resources/publications/dmp-handbook/ section-11.asp\#section11_1> (Accessed September 8, 2010).

41. Sam JJ, Heathcote EJ, Wong DK, Wooster DL, Shah H. Hepatitis B learning needs assessment of family medicine trainees in Canada: Results of a nationwide survey. Can J Gastroenterol 2011;25:127-34. 


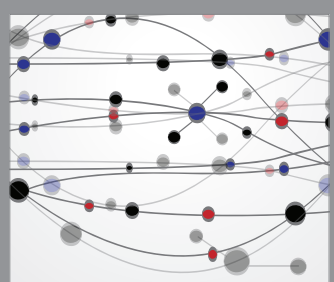

The Scientific World Journal
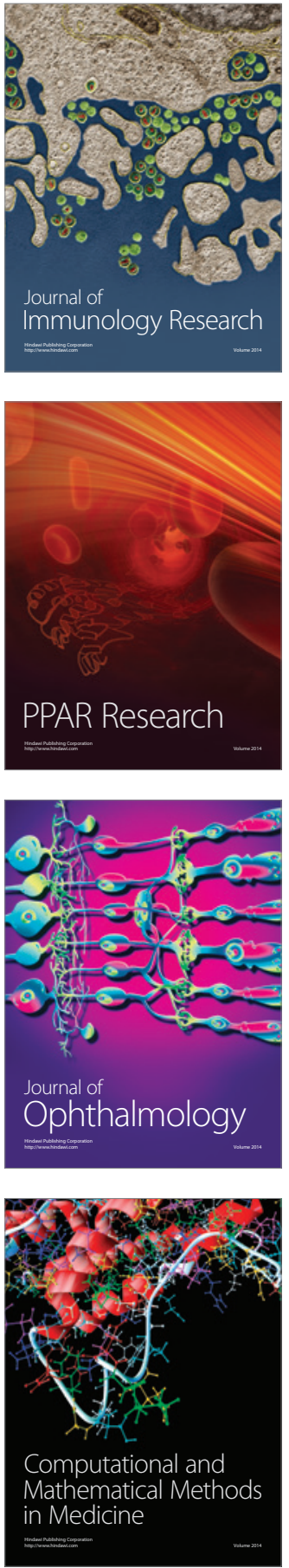

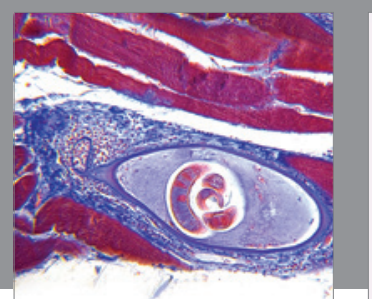

Gastroenterology Research and Practice

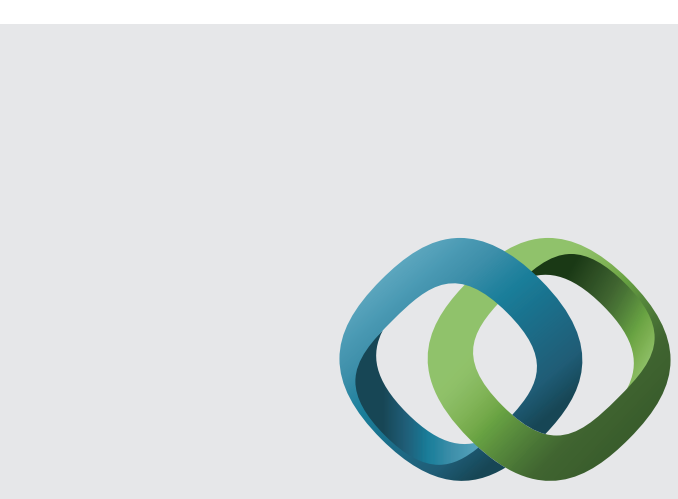

\section{Hindawi}

Submit your manuscripts at

http://www.hindawi.com
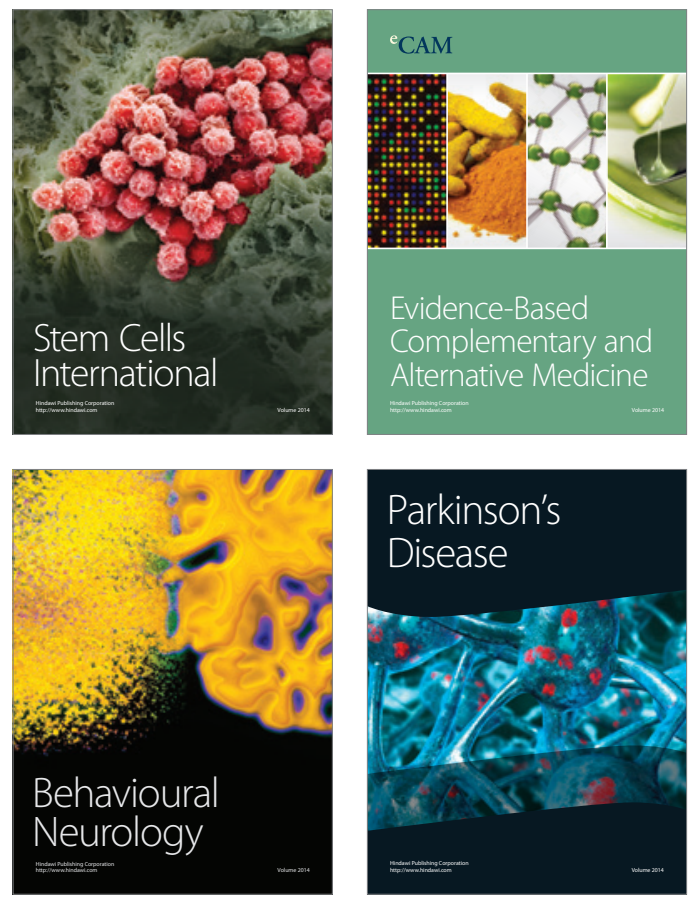
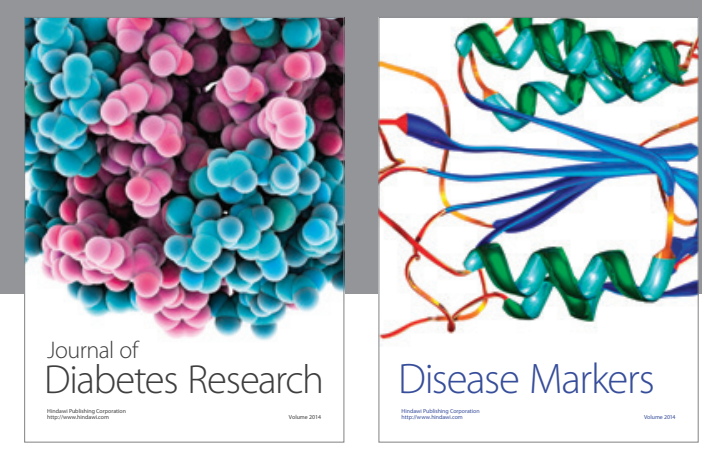

Disease Markers
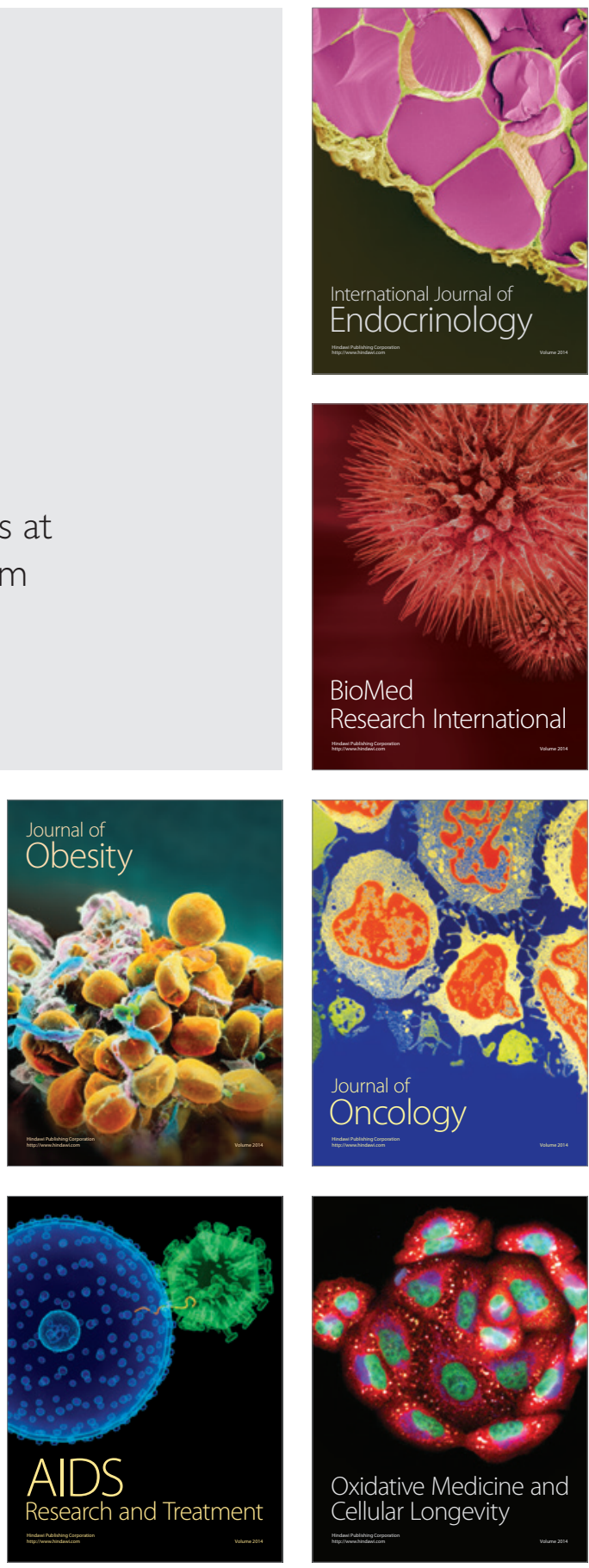